\title{
Analysis of Current Status of Human Resource Management and Development at Colleges and Universities and Researches into Countermeasures
}

\author{
Shufeng $\mathrm{Ni}$ \\ Jilin Agricultural University \\ 512375850@qq.com
}

\begin{abstract}
Keywords: Colleges and universities; Human resource management and development; Analysis of current status; Research into countermeasures
\end{abstract}

\begin{abstract}
Many colleges and universities in China have relatively backward international status, but many of them have a long history and develop slowly because there are many problems in their human resources management and development, which has restricted the development of colleges and universities. Colleges and universities are places to cultivate talents, so in order to promote China's development, colleges and universities should reform their human resource management and development. Aiming at this point, this paper first analyzes the current status of human resource management and development at colleges and universities in China, and according to the actual situation, proposes corresponding strategies for improvement.
\end{abstract}

\section{Introduction}

Ever since the 21st century, the world's economy has been developing quickly with the acceleration of integration process. The talent market is also becoming globalized, thus competition between talents is becoming increasingly fierce. Colleges and universities are a kind of special existence, which plays a vital role in the development of a country. However, many colleges and universities in China develop very slowly because they have not realized the importance of managing and developing human resources. Besides, some colleges and universities have realized the importance of managing and developing human resources, but they have not formulated corresponding strategies to improve the management and development of human resources, thus they develop very slowly with backward international reputation.

\section{Analysis of the Current Status of Human Resource Management and Development at Colleges and Universities}

The Human Resource Management and Development System at Colleges and Universities Is not Perfect. Nowadays, many colleges and universities in China have not fully realized the importance of managing and developing human resources, so they do not pay attention to human resource management and development, naturally do not formulated relevant systems or their current systems are not perfect, which is mainly manifested in that: many schools only implement policies according to their superior's files without considering their own actual situation. Although some other colleges and universities have relevant systems, they are to a large extent random and often violate the system due to the will of some individual leaders.

Human Resource Management and Development at Colleges and Universities Lack Long-Term Planning. Many colleges and universities do not have long-term plans for human resource management and development, so they cannot determine talent management, cultivation and introduction system according to their own situation. Then colleges and universities cannot guarantee sufficient talents for a long run. Besides, even if talents have been introduced, due to the lack of long-term plan, they cannot cultivate these talents nor retain these talents so that brain drain is very serious. 
Colleges and Universities' Human Resource Management and Development Mechanism Is Unreasonable. Many colleges and universities only focus on things in management without studying human beings, so they have not fully realized the importance of managing people in managing and developing human resources at colleges and universities. Consequently, they are unable to construct a set of reasonable human resource management and development mechanism at colleges and universities. Sometimes, colleges and universities can blindly introduce some talents, but these people fail to give play to their talents afterwards. Besides, many colleges and universities lack enough professional teachers in some fields, leading to the imbalanced development of each major at colleges and universities. Distribution is also a part of human resource management and development, so many colleges and universities have also advanced with the times and established a competition and motivation mechanism. But there are also various problems in the specific implementation process, such as the imperfect assessment system, thus the motivation mechanism cannot be fair and just.

\section{Research into Measures to Manage and Develop Human Resources at Colleges and Universities}

Improve Human Resource Management and Development System at Colleges and Universities. No matter what you do, you must have the appropriate code of conduct, for the university, want to do a good job in human resources management and development, then we must improve the relevant system. Along with the deepening of economic globalization process, the talent market is becoming globalization, professional talent not only in the domestic popular, in the international is also popular, which leads to the aggravation of the competition for talent, if not perfect relevant system, then the university will not be able to contention from required talents. Want to compete for talent, in essence, is the human resources management and development system of competition, because only a good system, to be able to attract talent, retain talent. Therefore, colleges and universities should establish the relevant appointment system, distribution system and evaluation system. After the development of the system, we must strengthen the implementation and supervision and management, so that the human resources management and development system can be effectively implemented.

Formulate Long-Term Human Resource Management and Development Plans at Colleges and Universities. Although colleges and universities are like corporations essentially, there are great differences between them, i.e., the significance of colleges and universities are to impart knowledge and educate people so as to cultivate talents in various fields for the country. Thus it can be said that colleges and universities are places to cultivate human resources, so they should naturally do a good job in human resource management and development, which is conducive to the development of colleges and universities. A most notable example is the Hong Kong University of Science and Technology, which enjoys great reputation now both in China and internationally. However, it began to recruit students since 1991, so its development history is only 25 years. On the contrary, many colleges and universities in China have a history of more than one hundred, but their international reputation cannot parallel with Hong Kong University of Science and Technology. In the final analysis, it is because Hong Kong University of Science and Technology formulated long-term human resource management and development plans since the beginning, so it can harvest today's achievement. It can be seen from this that long-term human resource management and development is very important for colleges and universities, but it also involves various aspects of human resources, including not only perfect talent introduction plans, but also talent cultivation and attraction plans, etc. Therefore, colleges and universities should formulate long-term plans from the several four aspects to do a good job in human resource management and development so as to promote their own development.

First of all, colleges and universities should be fully aware of the current situation of human resource management and development and start from the actual situation at the current stage to consider human resources needed recently and in the future in order to obtain development. Of course, colleges and universities should also combine their development goals to formulate 
long-term plans according to their final development targets. Besides, they need to formulate more than one set of long-term plans so that they can timely take corresponding measures while encountering problems. For problems existing in the current stage of human resource management and development, colleges and universities should actively adjust them so as to get better allocation of human resources.

Secondly, colleges and universities should divide their long-term plans into detailed categories and formulate several short-term plans so that they can timely find out whether they are advancing towards the goal of their long-term plans. Besides, once they fail to achieve goals of short-term plans, they should find the problems and modify them.

Then, while formulating long-term plans, colleges and universities should determine the key point, which is to introduce, cultivate and retain excellent talents. The introduction of excellent talents should be determined according to demands of the subjects and majors so as to advance towards the goal of cultivating subject leaders and retain talents is to keep those capable talents and excellent talents while avoid brain drain.

Finally, while formulating long-term plans, colleges and universities should start from the global perspective and clarify their goals. In order to effectively implement long-term plans, colleges and universities should also formulate relevant policies so that long-term plans can be smoothly carried out.

Establish Reasonable Human Resource Management and Development Mechanism at Colleges and Universities. In order formulate reasonable human resource management and development mechanism at colleges and universities, it should be started from the following four aspects:

First of all, formulate reasonable talent introduction mechanism. Colleges and universities are essentially the same with enterprises, so in order to develop, they cannot be separated from talents. However, a college or university involves a large number of disciplines and majors, so they should formulate talent introduction plans according to different disciplines' requirements. While introducing talents, they should also pay attention to assessing talents in both professional knowledge and virtue. After all, colleges and universities are a place to impart knowledge and educate people, so if teachers lack one of the two, they cannot complete this task. In terms of expanding talent introduction channels, in addition to field recruitment, online recruitment can also be adopted. Thus, colleges and universities should not rigidly adhere to the form of recruitment, but should try everything to attract useful talents. For each subject of professional leaders, but also should be actively selected, and the employment of useful personnel can be part-time, can also be cooperative, not necessarily full-time, this is also conducive to the development of colleges and universities. Talents in Colleges and universities should pay attention to the study of professional knowledge. Therefore, it should be in the recruitment of the time set up specialized talent introduction work group, to the president of a university as a team leader, the dean of each college as a member of the group, completed the work of introducing talents. In the study of the ability of the time, can be carried out by the various colleges, colleges and the ability of a relatively strong group of teachers to conduct selection activities. In the introduction of talent, to the actual situation of the actual analysis, according to the actual situation flexibly.

Second, formulate reasonable talent appointment mechanism. After talents are introduced, they should naturally be appointed so that the role of talents can be played. Therefore, colleges and universities should formulate reasonable talent appointment mechanism. In appointing talents, one principle should be followed, i.e. to give full play to each talent's talent and appoint talents in a scientific and reasonable way, regardless of what kind of talent, should provide development space, making it able to play to their talents, so that they can mobilize their work along the initiative. Appointment of personnel, should be bold, for those who have a good development potential of the young teachers, should be put in practice to cultivate, so they can bear the important task, in the work can give full play to their talents, so as to cultivate a group belongs to the University I's own talent. In the appointment of personnel, be sure to eliminate cronyism, follow the principles of fairness, impartiality and openness, to every personnel are placed on the most reasonable position. 
Appointment mode can choose appointment system, which is the current reform of human resources in our country. Once the beginning of the implementation of the employment system, it can effectively change before eating from the same big pot to put those who occupy a position but did not play the role of people excluded, making everyone can actively work, but also can realize distribution according to work.

Then, make reasonable talent retention mechanism. For colleges and universities, on the basis of doing well in the introduction, appointment, but also should retain talent, the loss of the prevention and control of talent, this should establish a talent retention mechanism. To retain talent, we should create a good environment, including the human environment, including work, life and social environment. The so-called humane environment, that is the interpersonal relationship between the teachers, a good interpersonal relationship, also can retain teachers, for university human resources management departments should help teachers to coordinate interpersonal relationship, make the psychological can of colleges and universities have a passion. The environment of the so-called, that is the academic atmosphere, a has a professional teacher highly values academic atmosphere, so to create a strong academic atmosphere, again is to allow teachers to have the ability to play the place. Therefore, colleges and universities should give these professionals greater space for the development of the in colleges and universities to create his own career. The so-called living environment, refers to the university teachers should enjoy the perfect welfare treatment, so that their life is comfortable, can concentrate on work to go, but also to retain talent. The so-called social environment, refers to the social security system, including medical insurance, social insurance and so on, only to create a good social environment, it can help the university to retain talent.

Finally, formulate reasonable talent motivation mechanism. To give full play to the talent, then the incentive is essential, through incentives, to realize the survival of the fittest to the greatest degree of play a person's ability, so that the results of a virtuous circle. Incentive can be implemented from two aspects, one is the material motivation, one is the spiritual motivation. Material motivation refers to the motivation of content is material, such as payment of salaries, payment of benefits and so on are material incentive; spiritual motivation refers to the natural is the contents of the incentive is the spirit, like is awarded the honorary title of teachers, teachers that give the opportunity and so on. The role of material and spiritual incentives is equally important, regardless of which aspect, it cannot play the role of incentives. Therefore, colleges and universities should combine material incentives and spiritual incentives to combine the two together so as to fully arouse the enthusiasm of all staffs of colleges and universities. Then the incentive mechanism should be combined with the distribution mechanism, so that each employee can have their own needs satisfied and work with full enthusiasm.

Colleges and universities are a very special existence in China, and they are like enterprises in some aspects, but different from enterprises to a large extent in some other aspects. Colleges and universities are to cultivate talents for China, so they should do a good job in human resource management and development. However, at the current stage, throughout the current status of human resource management and development in China, many problems can be found, and due to these problems, colleges and universities in China are unable to go a good job in human resource management and development, so they cannot progress to improve their own status. Therefore, colleges and universities should carry out comprehensive reform and improve human resource management and development so as to cultivate more excellent talents for China and promote national progress.

\section{References}

[1] Dong Jie, Xu Honglin. Analysis of Current Status of Teaching Human Resources Management at Colleges and Universities in China and Countermeasures [J]. Journal of Shandong Youth University of Political Science, 2005, 04:84-85.

[2] Li Xuefeng. Analysis of Current Human Resource Management at Colleges and Universities and Research into Countermeasures [J]. Knowledge Economy, 2015, 23:154. 
[3] Wan Qiucheng. Current Status of Human Resource Management at Colleges and Universities and Countermeasures [J]. Business Times, 2007, 01:58-59.

[4] Wang Wei. Research into Measures to Manage and Develop Human Resources at Colleges and Universities [J]. Adult Education, 2007, 01:59-60.

[5] Jing Hongbin, Yang Jun. Problems in Developing and Managing Human Resources at Colleges and Universities and Countermeasures [J]. Journal of Panzhihua University, 2009, 04:36-40.

[6] Aiguri Abdurixit, Research into Measures to Develop and Manage Human Resources at Colleges and Universities [J]. Journal of Hubei Correspondence University, 2011, 01:12-13.

[7] $\mathrm{Xu}$ Xunfeng. Current Status of Human Resource Management at Colleges and Universities in China and Research into Countermeasures [J]. Research into University Logistics, 2011, 01:49-51.

[8] Zhang Zhi, Huang Bo, Huang Lun. Current Status of Human Resource Management at Colleges and Universities in China in the New Period and Research into Countermeasures [J]. Neijiang Science and Technology, 2008, 02:3+21.

[9] Chen Jun. Current Status of Human Resource Management at Local Colleges and Universities and Research into Countermeasures [J]. Journal of Hubei Polytechnic University (Human Science Edition), 2008, 05:38-41.

[10]Liu Xifa. Human Resource Management at Local Colleges and Universities and Research into Countermeasures [J]. Research into Productivity, 2008, 19:94-96. 